\title{
Life Cycle Assessment of Biofertilizer Production and Use Compared with Conventional Liquid Digestate Management
}

Styles, David; Adams, Paul; Thelin, Gunnar; Vaneeckhaute, Celine; Chadwick, David; Withers, Paul

\section{Environmental Science and Technology}

DOI:

10.1021/acs.est.8b01619

Published: 03/07/2018

Peer reviewed version

Cyswllt i'r cyhoeddiad / Link to publication

Dyfyniad o'r fersiwn a gyhoeddwyd / Citation for published version (APA):

Styles, D., Adams, P., Thelin, G., Vaneeckhaute, C., Chadwick, D., \& Withers, P. (2018). Life Cycle Assessment of Biofertilizer Production and Use Compared with Conventional Liquid Digestate Management. Environmental Science and Technology, 52(13), 7468-7476. https://doi.org/10.1021/acs.est.8b01619

\footnotetext{
Hawliau Cyffredinol / General rights

Copyright and moral rights for the publications made accessible in the public portal are retained by the authors and/or other copyright owners and it is a condition of accessing publications that users recognise and abide by the legal requirements associated with these rights.

- Users may download and print one copy of any publication from the public portal for the purpose of private study or research.

- You may not further distribute the material or use it for any profit-making activity or commercial gain

- You may freely distribute the URL identifying the publication in the public portal ?
}

Take down policy

If you believe that this document breaches copyright please contact us providing details, and we will remove access to the work immediately and investigate your claim. 
1 Life cycle assessment of biofertilizer production and use compared with 2 conventional liquid digestate management

3

4 David Styles ${ }^{\mathrm{a}, \mathrm{b}^{*}}$, Paul Adams ${ }^{\mathrm{c}}$, Gunnar Thelin ${ }^{\mathrm{d}}$, Céline Vaneeckhaute ${ }^{\mathrm{e}}$, David Chadwicka, Paul J. A. 5 Withers $^{\mathrm{a}}$

6 aSchool of Environment, Natural Resources and Geography, Bangor University, Bangor, Wales, LL57

$72 U W$

8 bPlant and AgriBiosciences Centre, National University Ireland Galway, Galway, Ireland, H91TK33

9 'Department of Mechanical Engineering, Bath University, North East Somerset, BA2 7AY, UK.

10 dEkoBalans Fenix AB, Scheelevägen 22, 22363 Lund, Sweden

$11{ }^{e}$ Chemical Engineering Department, Université Laval, 1065 avenue de la Médecine, Québec QC, 12 Canada, G1V 0A6

13 *Corresponding author: $\underline{\text { d.styles@bangor.ac.uk }}$

14

15 
Graphical abstract

17

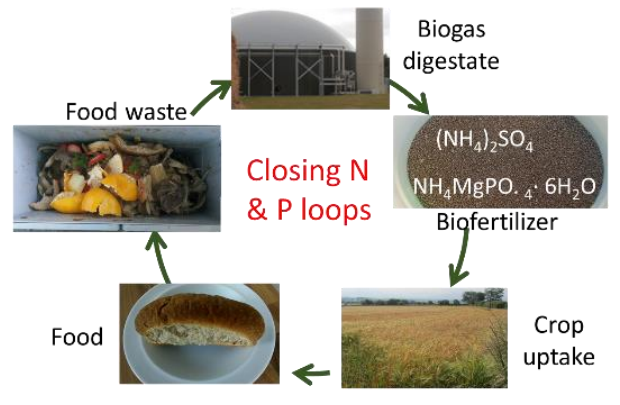


Handling of digestate produced by anaerobic digestion impacts the environment through emission of greenhouse gases, reactive nitrogen and phosphorus. Previous life cycle assessments (LCA) evaluating the extraction of nutrients from digestate using struvite precipitation and ammonia stripping did not relate synthetic fertilizer substitution (SFS) to nutrient use efficiency consequences. We applied an expanded LCA to compare the conventional management of $1 \mathrm{~m}^{3}$ of liquid digestate (LD) from food waste against the production and use of digestate biofertilizer (DBF) extracted from $\mathrm{LD}$, accounting for SFS efficacy. Avoidance of $\mathrm{CH}_{4}, \mathrm{~N}_{2} \mathrm{O}$ and $\mathrm{NH}_{3}$ emissions from $\mathrm{LD}$ handling and enhanced SFS via more targeted use of nutrients in the versatile DBF product could generate environmental savings of up to $0.129 \mathrm{~kg} \mathrm{Sb}$ eq., $4.16 \mathrm{~kg} \mathrm{SO}_{2}$ eq., $1.22 \mathrm{~kg} \mathrm{PO}_{4}$ eq., $33 \mathrm{~kg} \mathrm{CO} 2$ eq. and 20.6 MJ eq. per $\mathrm{m}^{3} \mathrm{LD}$, for abiotic resource depletion, acidification, eutrophication, global warming and cumulative energy demand burdens, respectively. However, under worst-case assumptions, DBF extraction could increase global warming and cumulative energy demand by $7.5 \mathrm{~kg} \mathrm{CO}_{2} \mathrm{e}$ and $251 \mathrm{MJ}$ eq. per $\mathrm{m}^{3} \mathrm{LD}$ owing to processing inputs. Normalizing these results against per capita environmental loadings, we conclude that DBF extraction is environmentally beneficial.

Keywords: digestate; expanded life cycle assessment; struvite; anaerobic digestion; greenhouse gases; ammonia; environmental burdens 


\section{Introduction}

42

43

44

Leaky nutrient cycles undermine the environmental sustainability of global food chains. The nitrogen (N) cycle is the second most critically impacted planetary system ${ }^{1}$. Pollution arising from $\mathrm{N}$ losses to air and water costs up to 320 billion euros annually across Europe $\mathrm{e}^{2,3}$ and manufacturing synthetic $\mathrm{N}$ fertilizer via the Haber-Bosch process is energy-intensive and expensive. Meanwhile, phosphorus (P) use efficiency is low, leading to eutrophication impacts in water bodies and depletion of poorlyquantified but essentially finite global phosphate reserves ${ }^{4,5}$. Closing nutrient cycles and minimising losses is therefore an imperative for sustainable food production. Anaerobic digestion (AD) is an increasingly popular option for the treatment of organic wastes, such as manures and food waste, that facilitates nutrient recycling whilst producing bio-energy ${ }^{6}$. The digestate co-product of $A D$ is a valuable bio-fertilizer, rich in readily available macro- and micro-nutrients ${ }^{7}$. However, storage and application of digestate gives rise to fugitive emissions of methane $\left(\mathrm{CH}_{4}\right)$ and ammonia $\left(\mathrm{NH}_{3}\right)$, contributing towards global warming, acidification and eutrophication ${ }^{8}$, whilst digestates from some feedstocks have been linked with increased risk of soil contamination with $\mathrm{Cu}, \mathrm{Zn}$ and $\mathrm{Mn}^{9}$. Economies of scale favour large AD plants to treat food waste, whilst a high water content makes long-term storage and long-distance transport of digestate uneconomic ${ }^{10}$. Digestate certification schemes ${ }^{11}$ have not yet overcome farmer suspicion about the agronomic value and safety of digestates which vary considerably in composition and deviate from ideal ratios for crop nutrition ${ }^{9}$. Consequently, there is concern that digestate is not distributed widely enough, nor applied at the right times, to achieve efficient nutrient use, i.e. digestate may be over-applied in areas adjacent to large $A D$ plants ${ }^{12}$ and in autumn when crop-uptake and $\mathrm{N}$ use efficiency is low ${ }^{9,13}$. A recent life cycle assessment (LCA) study ${ }^{14}$ found that, even when digestate from food waste is applied at agronomically-appropriate times, field emissions outweigh fertilizer substitution credits, leading to net acidification and eutrophication burdens. Mechanical separation of digestate into solid fractions containing more of the $P$, and liquid fractions containing more of the $\mathrm{N}$ and $\mathrm{K}$, could help to improve nutrient use efficiency, as demonstrated for separated pig slurry ${ }^{15}$. However, it may also increase $\mathrm{N}_{2} \mathrm{O}$ emissions from the solid 
fraction ${ }^{16}$. Handling separated liquid digestate (LD) still gives rise to distribution challenges and ammonia emissions ${ }^{8,9}$. Upgrading digestate into a concentrated, easy-to-handle biofertilizer is a potential solution that could improve nutrient use efficiency and reduce emissions by avoiding prolonged storage of digestate, and by concentrating nutrients into a compact, convenient and familiar powder fertilizer format that can be applied in accordance with crop requirements ${ }^{5}$. A range of technologies have been developed to upcycle digestate, including struvite precipitation, ammonia stripping and capture (absorption/crystallisation), acidification and alkaline stabilisation ${ }^{17}$, algal nutrient-stripping ${ }^{18}$ and others. In this paper, we focus on struvite precipitation with ammonia stripping to produce a digestate biofertilizer (DBF) product, the most established technologies ${ }^{17}$. These technologies could also be applied to address problems associated with nutrient over-concentration in regions with high livestock densities and constrained landbanks for manure spreading, e.g. periurban livestock systems in Asia.

Despite promising field trials valorising the crop nutrient value of such biofertilizers, legislative barriers have hitherto limited their development ${ }^{9,19}$. A recent LCA study highlighted environmental benefits and trade-offs associated with LD upcycling to $\mathrm{DBF}^{20}$, but did not account for potential fertilizer substitution effects linked to more precise nutrient management, which could be particularly significant in the context of a rapidly expanding global AD sector. The common assumption of 1:1 substiution of synthetic fertilizer nutrients with organic nutrients frequently leads to overestimation of the environmental performance of conventional organic residue use in LCA studies ${ }^{21}$. For the first time, this study accounts for important nutrient use efficiency effects within an expanded boundary LCA to fully compare the environmental balance of conventional LD management with production and use of an upcycled DBF product. We build on recent LCA studies of digestate upcycling ${ }^{8,20}$ with new detailed data on DBF processing obtained from bench and pre-commercial pilot trials undertaken by a Swedish company ${ }^{22}$, and apply detailed accounting for emissions and fertilizer substitution arising from different management of LD based on appropriate models and emission factors ${ }^{23-25}$. 


\section{Materials and Methods}

\subsection{Biofertilizer production process}

Mechanical dewatering of whole digestate from food waste AD plants produces a solid digestate fraction, into which more of the $\mathrm{P}$ is partitioned, and a LD fraction, into which more of the $\mathrm{N}$ (especially $\mathrm{NH}_{4}-\mathrm{N}$ ) and $\mathrm{K}$ is partitioned ${ }^{10}$. Here, we focus on extraction and upcycling of a digestate biofertilizer (DBF) from the LD fraction, and benchmark the performance of the DBF life cycle with the baseline LD life cycle. Technical data on DBF production from LD produced at a centralized food waste AD plant was taken from bench- and pre-commercial pilot trials in Sweden ${ }^{22}$. The DBF is produced via the Ekobalans eco:P and eco:N processes. The eco:P process involves struvite (magnesium ammonium phosphate) precipitation via the addition of magnesium chloride and $\mathrm{pH}$ control by aeration, and crystallised precipitation of $\mathrm{P}$. The eco: $\mathrm{N}$ process involves the air-stripping of ammonia from liquid digestate flowing down through a packed column, followed by crystallization recovery using sulphuric acid to produce solid ammonium sulphate $\left(\left(\mathrm{NH}_{4}\right)_{2} \mathrm{SO}_{4}\right)$ at $21 \% \mathrm{~N}$ content. The efficiency of this technique is improved by increasing the temperature and the $\mathrm{pH}$ of the digestate using sodium hydroxide $(\mathrm{NaOH})^{22,26} . \mathrm{N}$ and $\mathrm{P}$ extracted in struvite and ammonium sulphate are blended with potassium chloride $(\mathrm{KCl})$ to produce the DBF product - a balanced NPK compound fertilizer.

\subsection{Goal, scope and boundary definition}

The primary goal of the study was to compare conventional management of LD with the production and use of DBF in terms of resource use efficiency and environmental impact. The primary research question is: does the upcycling of LD into DBF lead to net environmental benefits and resource savings? The answer to this question is pertinent to waste managers, farmers and policy makers.

We undertook a "gate-to-grave" LCA in accordance with $\mathrm{ISO}^{27}$ principles to benchmark the environmental performance of DBF production and use against typical handling of LD from centralised AD plants. The functional unit was the handling of $1 \mathrm{~m}^{3}$ of $L D$ from a food waste AD plant (Table S1). System boundaries for conventional LD and DBF management begin immediately following 
separation, representing the point of divergent management from existing best practice, and capturing major post-digestion environmental burdens of LD management (Fig. 1). Management of the solid digestate fraction is unaffected by DBF extraction and excluded from the analyses. To reflect important implications for synthetic fertilizer substitution, system boundaries were expanded to account for synthetic fertilizer replacement achieved by field-application of LD and DBF in terms of avoided field emissions and fertilizer manufacture. Capital equipment such as farm machinery and upgrading facilities are outside the system boundary ${ }^{28}$. Operational flows of digestate are expected to

124 be thousands of $\mathrm{m}^{3}$ a month over twenty or more years, leading to small burden contributions from construction and maintenance. The effects of varying transport distances, digestate storage infrastructure, field application methods and nutrient management planning (NMP) were explored 127 using scenarios. Life cycle inventories are described below. Five impact categories pertinent to AD and 128 agricultural systems were selected from the $\mathrm{CML}$ baseline method ${ }^{29}$ to represent environmental impact and resource efficiency: abiotic resource depletion potential (ARDP), expressed as kg Sb eq.; acidification potential (AP), expressed as $\mathrm{SO}_{2}$ eq.; cumulative energy demand (CED), expressed as MJ eq.; eutrophication potential (EP), expressed as $\mathrm{PO}_{4}$ eq.; global warming potential (GWP), expressed as $\mathrm{CO}_{2}$ eq. 


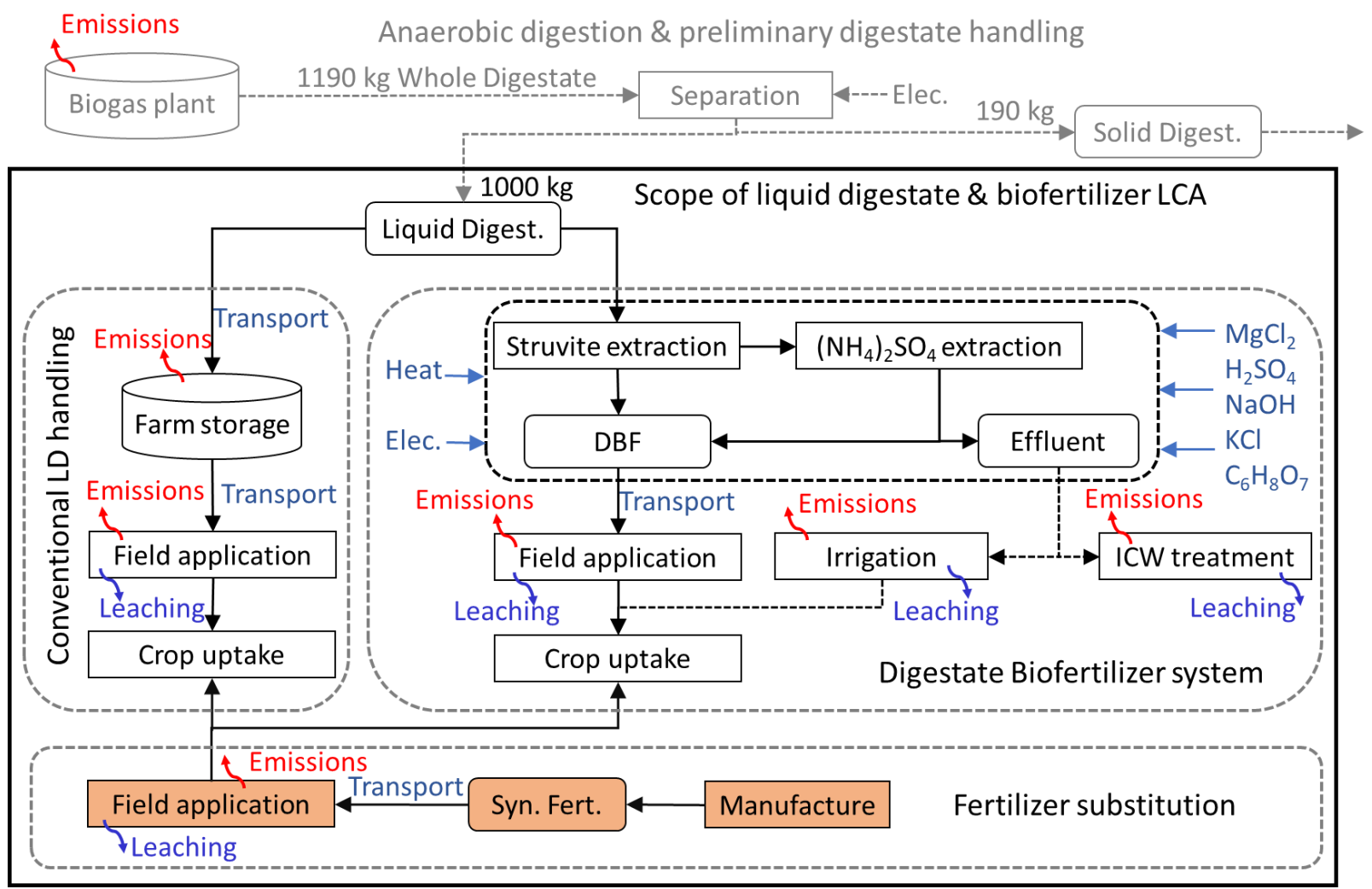

Figure 1. Main processes and inputs accounted for in this study, within system boundaries for (i) conventional liquid digestate (LD) handling and (ii) digestate biofertilizer (DBF) production and use, including synthetic fertilizer substitution, but excluding preliminary digestate management common to both systems.

Results were calculated for different management practices and contexts through consideration of four scenarios of conventional LD management and three scenarios of DBF production and use (Table 1). Uncertainty ranges for each scenario were calculated by propagating specific methodological uncertainties detailed in sections 2.3 and 2.4 in quadrature (square root of summed squared errors), expressed as error bars on results. the type of digestate storage and application ${ }^{10,14,30,31}$. Sensitivity analyses were therefore applied through scenarios to evaluate different storage and application options, and varying transport distances to farms (Table 1). A major challenge for efficient use of LD is convincing a sufficient number of farmers within an economic transport distance to spread it in accordance with good nutrient 

replacement achieved by field application of LD, by multiplying maximum potential fertilizer replacement values calculated in MANNER-NPK ${ }^{23}$ by $25 \%, 50 \%, 75 \%$ and $100 \%$ (Table 1 ).

Table 1. Scenario permutations for liquid digestate (LD) and digestate biofertilizer (DBF) management

\begin{tabular}{|c|c|c|c|c|}
\hline $\begin{array}{l}\text { Liquid digestate } \\
\text { scenario }\end{array}$ & $\begin{array}{l}\text { Transport } \\
\text { distance }(\mathrm{km})\end{array}$ & $\begin{array}{l}\text { Storage location } \\
\text { and infrastructure }\end{array}$ & $\begin{array}{l}\text { Field application } \\
\text { technique }\end{array}$ & $\begin{array}{l}\text { Fertilizer } \\
\text { replacement (\% } \\
\text { available NPK*) }\end{array}$ \\
\hline LD-1 (optimum) & 5 & $\begin{array}{l}\text { Biogas plant, } \\
\text { sealed tank }\end{array}$ & Shallow injection & $100 \%$ \\
\hline LD-2 (good case) & 10 & $\begin{array}{l}\text { Farm, covered } \\
\text { tank }\end{array}$ & Shallow injection & $75 \%$ \\
\hline LD-3 (default) & 10 & Farm, open tank & Trailing hose & $50 \%$ \\
\hline LD-4 (worst case) & 20 & Farm, lagoon & Trailing hose & $25 \%$ \\
\hline $\begin{array}{l}\text { Digestate } \\
\text { biofertilizer } \\
\text { scenario }\end{array}$ & $\begin{array}{l}\text { Transport } \\
\text { distance }(\mathrm{km})\end{array}$ & Electricity source & Heat source & $\begin{array}{l}\text { Effluent } \\
\text { management }\end{array}$ \\
\hline DBF-1 (optimum) & 20 & $\begin{array}{l}\text { Nuclear/ } \\
\text { renewable }\end{array}$ & $\begin{array}{l}\text { Biogas-CHP waste } \\
\text { heat }\end{array}$ & Crop-irrigation \\
\hline DBF-2 (default) & 50 & NG-CCT & Gas boiler & $\begin{array}{l}\text { Constructed } \\
\text { wetland }\end{array}$ \\
\hline DBF-3 (worst case) & 200 & Coal & Gas boiler & $\begin{array}{l}\text { Constructed } \\
\text { wetland }\end{array}$ \\
\hline
\end{tabular}

Life cycle inventories were compiled to account for all inputs and outputs from processes arising

within the respective system boundaries. The first stage of conventional LD handling is transport to the farm using a bulk liquid tanker over $10 \mathrm{~km}$, varied from 5 to $20 \mathrm{~km}$ (Table 2). In the default scenario, LD is stored in an open tank on the farm. Alternative scenarios involve a tank with a natural crust or floating cover, a lagoon storage system, or longer storage of separated liquid digestate at the centralised digester plant in a sealed tank prior to direct field-application (Table 1). Methane emissions were calculated using the following equation: 
164 where volatile solids (VS) content of the LD fraction is $12.8 \mathrm{~kg} \mathrm{~m}^{-3}$ (Banks, 2011), $\mathrm{CH}_{4}$ generating 165 capacity (Bo) is $0.2 \mathrm{~m}^{3} \mathrm{~kg}^{-125,32}$, methane density is $0.714 \mathrm{~kg} \mathrm{~m}^{-3}$, and methane conversion factor (MCF) 166 is expressed in relation to the type of storage system ${ }^{33}$, ranging from $1 \%$ (sealed tank), through $10 \%$ 167 (covered tank) to $17 \%$ (open tank and lagoon). $\mathrm{NH}_{3}-\mathrm{N}$ emission factors were applied to $\mathrm{NH}_{4}-\mathrm{N}$ in the 168 LD depending on the type of storage system, ranging from 2\% (sealed tank), 5\% (covered tank) through $16910 \%$ (open tank) to $52 \%$ (lagoon) ${ }^{24} \cdot \mathrm{N}_{2} \mathrm{O}$ emissions from storage of LD in tanks and lagoon systems 170 were assumed to be negligible, as reported in previous studies ${ }^{25}$ and consistent with GHG accounting 171 guidelines for liquid slurry systems ${ }^{33}$. Table 2 presents $\mathrm{CH}_{4}$ and $\mathrm{NH}_{3}$ emissions from the four scenarios 172 of digestate storage. 
Table 2. Inventory of inputs and direct emissions for a reference flow of $1 \mathrm{~m}^{3}$ of liquid digestate (LD) exiting an anaerobic digestion plant and either sent to nearby farms where it may be managed along a spectrum of best to worst practices (LD-1 to LD-4; Table 1), or upcycled to digestate biofertilizer (DBF)

175 for use on farms further away (DBF-1 to DBF-3; Table 1).

\begin{tabular}{|c|c|c|c|c|c|c|c|c|}
\hline Stage & Process & LD-1 & LD-2 & LD-3 & LD-4 & DBF & Units & References \\
\hline \multirow{4}{*}{$\begin{array}{l}\text { LD transport } \\
\text { \& storage }\end{array}$} & Trans. to farm & 5.00 & 10.00 & 10.00 & 20.00 & 0.69 & Tkm & \\
\hline & Storage $\mathrm{CH}_{4}$ & 0.02 & 0.18 & 0.31 & 0.31 & - & $\mathrm{Kg}$ & $25,32,33$ \\
\hline & Storage $\mathrm{NH}_{3}$ & 0.03 & 0.08 & 0.41 & 2.12 & - & $\mathrm{Kg}$ & 24 \\
\hline & Storage $\mathrm{N}_{2} \mathrm{O}$ & 0 & 0 & 0 & 0 & - & $\mathrm{Kg}$ & 25,33 \\
\hline \multirow{2}{*}{$\begin{array}{l}\text { Struvite } \\
\text { extraction }\end{array}$} & $\mathrm{MgCl}_{2 .} 6 \mathrm{H}_{2} \mathrm{O}$ & - & - & - & - & 0.85 & $\mathrm{Kg}$ & 22 \\
\hline & Electricity & - & - & - & - & 0.70 & kWh & 22 \\
\hline \multirow{5}{*}{$\begin{array}{l}\text { Ammonium } \\
\text { sulfate } \\
\text { extraction }\end{array}$} & $\mathrm{NaOH} 50 \%$ & - & - & - & - & 10.00 & $\mathrm{Kg}$ & 22 \\
\hline & $\mathrm{H}_{2} \mathrm{SO}_{4} 96 \%$ & - & - & - & - & 11.00 & $\mathrm{Kg}$ & 22 \\
\hline & Electricity & - & - & - & - & 1.10 & kWh & 22 \\
\hline & Heat & - & - & - & - & 16.00 & kWh & 22 \\
\hline & Citric acid & - & - & - & - & 0.28 & $\mathrm{Kg}$ & 22 \\
\hline \multirow{3}{*}{$\begin{array}{l}\text { Fertilizer } \\
\text { production }\end{array}$} & $\mathrm{KCl}$ & - & - & - & - & 0.019 & $\mathrm{Kg}$ & 22 \\
\hline & Electricity & - & - & - & - & 0.002 & kWh & 22 \\
\hline & Heat & - & - & - & - & 0.014 & kWh & 22 \\
\hline \multirow{5}{*}{$\begin{array}{l}\text { Field } \\
\text { application }\end{array}$} & Diesel consum. & 0.75 & 0.75 & 0.50 & 0.50 & 0.004 & $\mathrm{Kg}$ & 34,35 \\
\hline & $\mathrm{NH}_{3}$ & 0.38 & 0.38 & 0.81 & 0.54 & 0.003 & $\mathrm{Kg}$ & 23,24 \\
\hline & $\mathrm{N}_{2} \mathrm{O}$ & 0.087 & 0.085 & 0.085 & 0.056 & 0.053 & $\mathrm{Kg}$ & 33 \\
\hline & $\mathrm{N}$ leaching & 0.92 & 0.91 & 0.77 & 0.51 & 0.31 & $\mathrm{Kg}$ & 36 \\
\hline & P leaching & 0.0012 & 0.0012 & 0.0012 & 0.0012 & 0.0012 & $\mathrm{Kg}$ & 37,38 \\
\hline \multirow{3}{*}{$\begin{array}{l}\text { Fertilizer } \\
\text { substitution }\end{array}$} & Avoided fert-N & 2.16 & 1.60 & 0.88 & 0.29 & 3.14 & $\mathrm{Kg}$ & ${ }^{23} \mathrm{x}$ replacement factor (Table 1 ) \\
\hline & Avoided fert-P & 0.060 & 0.045 & 0.030 & 0.015 & 0.12 & $\mathrm{Kg}$ & ${ }^{23} \mathrm{x}$ replacement factor (Table 1 ) \\
\hline & Avoided fert-K & 1.27 & 0.95 & 0.64 & 0.32 & 1.00 & $\mathrm{Kg}$ & ${ }^{23} \mathrm{x}$ replacement factor (Table 1 ) \\
\hline \multirow{2}{*}{$\begin{array}{l}\text { DBF effluent } \\
\text { in ICW }\end{array}$} & Electricity & - & - & - & - & 0.12 & $\mathrm{kWh}$ & 39 \\
\hline & $\mathrm{N}_{2} \mathrm{O}$ & - & - & - & - & 0.016 & $\mathrm{Kg}$ & $40-42$ \\
\hline
\end{tabular}




\begin{tabular}{|ll|lllllll}
\hline DBF effluent & Electricity & - & - & - & - & 0.25 & & $\mathrm{kWh}$ \\
irrigation & $\mathrm{N}$ leaching & - & - & - & - & 0.025 & $\mathrm{Kg}$ & 23 \\
use (DBF-1 & $\mathrm{NH}_{3}$ & - & - & - & - & 0.030 & $\mathrm{Kg}$ & 23 \\
only) & $\mathrm{N}_{2} \mathrm{O}$ & - & - & - & - & 0.016 & $\mathrm{Kg}$ & 23 \\
& Avoided fert-N & - & - & - & - & 0.40 & $\mathrm{Kg}$ & 23 \\
& Avoided fert-K & - & - & - & - & 0.675 & $\mathrm{Kg}$ & 23 \\
\end{tabular}


Following 3-6 months of storage, LD is applied to land using either shallow injection (LD-1 and LD-2) or trailing hose (LD-3 and LD-4) application. Emissions of $\mathrm{NH}_{3}, \mathrm{NO}_{3}$ leaching and maximum NPKfertilizer replacement values were calculated using MANNER NPK ${ }^{23}$ for spring and autumn LD applications in good conditions (calm weather, moist soils, no rain immediately after application), on a medium textured soil prior to a spring cereal crop (see SI2). LD nutrient concentrations inputted into MANNER-NPK were corrected for storage losses of $\mathrm{N}$. Direct and indirect $\mathrm{N}_{2} \mathrm{O}$ emissions were calculated based on IPCC Tier $1^{43}$. Varying levels of NMP were represented by equating actual fertilizer replacement from 25 to $100 \%$ of replacement potential calculated using MANNER-NPK (Table 1). To reflect considerable uncertainty over emission factors, gaseous emissions and leaching losses were varied by $\pm 50 \%$ for each scenario.

Credits for avoided fertilizer use comprised avoided manufacture taken from the Ecoinvent database ${ }^{44}$ and avoided field emissions post-application based on emission factors of $0.017 \mathrm{NH}_{3}-\mathrm{N}^{24}, 0.1 \mathrm{NO}_{3}-\mathrm{N}^{36}$ and 0.01 for $\mathrm{P}$ following $\mathrm{N}$ - and $\mathrm{P}$-fertilizer application ${ }^{38}$. Nitrogen, phosphorus and potassium fertilizers were assumed to be in the forms of ammonium nitrate, triple superphosphate and potassium chloride. Diesel consumption for trailing hose and shallow injection application ${ }^{34,35}$ was multiplied by relevant tractor emissions ${ }^{38}$ and upstream production and supply burdens ${ }^{44}$. Uncertainty in transport and upstream burdens was reflected by varying these burdens by $\pm 20 \%$.

\subsection{Upcycled digestate biofertilizer production and use}

Digestate upcycling into DBF occurs in four stages: flocculation of suspended solids, struvite extraction, ammonium sulfate cystalisation and final fertilizer blending, with various heat, electricity and chemical inputs (Table 2). Three permutations of DBF production and use were considered (Table 1). Indirect emissions from heat, electricity and chemical production were taken from Ecoinvent ${ }^{44}$, with sensitivity analyses undertaken by varying electricity and heat sources. The default electricity source was natural gas combined cycle turbine (NG-CCT) power stations, representing typical marginal electricity generation ${ }^{45}$. Best- and worst-case permutations were based on a grid mix of $90 \%$ nuclear 
and renewable sources (current Swedish grid), and coal generation. The source of heat was varied between a natural gas condensing boiler (default) and waste heat from biogas combined heat and power generators (zero burden on assumption otherwise dumped). It was assumed that fugitive emissions from the upgrading process were negligible because the stripping air is circulated in a closed loop between the crystallizer and the ammonia stripping column. The DBF product was transported $50 \mathrm{~km}$ in a 16-32 t EURO V lorry ${ }^{44}$ for field application where needed, and in accordance with good NMP, resulting in 1:1 substitution of fertilizer NPK. Field emissions were calculated as per synthetic fertilizer (section 2.3), accounting for diesel consumption ${ }^{34}$. Uncertainty analyses were undertaken by varying the rate of fertilizer-P substitution by struvite-P from $100 \%$ down to $50 \%$, reflecting the findings of recent research on struvite as a slow-release fertilizer ${ }^{46}$, and varying heating, electricity and chemical requirements by $\pm 20 \%$.

Effluent water contains significant quantities of $\mathrm{N}$ and $\mathrm{K}$ (see $\mathrm{SI} 3$ ), and was assumed to be treated in a constructed wetland (default option) or returned to land as irrigation water (best case option). Field emissions and fertilizer replacement value for irrigation water were calculated using MANNER-NPK, assuming $1 \%$ residual dry matter content, "trailing hose" type irrigation, and taking the average of January, April, July and October applications to represent year-round irrigation (Table 2). Electricity requirements for pumping effluent to irrigation pipes and through a constructed wetland were taken from Plapally et al. $(2012)^{39}$. Nutrients contained in effluent sent to a constructed wetland will be retained in biomass and denitrified, giving rise to $\mathrm{N}_{2} \mathrm{O}$ emissions ${ }^{40-42}$ (Table 2). Effluent water treatment burdens were varied by $\pm 50 \%$.

\section{Results and discussion}

\subsection{Resource depletion and global warming}

Avoided fertilizer manufacture dominates ARDP and CED balances, which are negative for default LD management (LD-3) and good (LD-2) or optimum (LD-1) LD management options, reflecting a net 
environmental benefit arising from good agronomic use of LD via synthetic fertilizer substitution (Fig.

2 and Table S3). However, if LD is poorly managed so that synthetic fertilizer substitution is just $25 \%$ of the potential (LD-4), then ARDP and CED burdens arising from the transport and spreading of LD are greater than the fertilizer substitution credits. The latter situation represents inefficient agronomic use of LD, not applied in accordance with good NMP, at wrong time of year and/or to land and cropping systems that do not require the nutrients. Whilst it is assumed that most digestate from crop-fed $A D$ is returned to nearby cropping fields ${ }^{38,47,48}$, there is a lack of information on the management of digestate produced in food waste AD plants. Food waste AD plant operators may need to pay farmers to take digestate away, and there is evidence that digestate is being over-applied to land close to food waste AD plants ${ }^{12}$ so that conventional LD management could generate net ARDP and CED burdens. These outcomes are not reflected in LCA studies that typically assume either all, or all plant-available, nutrients in digestate substitute synthetic fertilizers ${ }^{31,47,49,50}$, confirming the need to improve the transparency and accuracy of fertilizer substitution in agronomic LCA studies. ${ }^{21}$

Extracted DBF performs almost twice as well as LD, even when LD is managed optimally (LD-1) in terms of ARDP, owing to more effective synthetic fertilizer substitution, but leads to a CED burden for DBF2 and DBF-3 almost three times greater than even poorly-managed LD (LD-4). This is partly because of high embodied energy in the chemicals required in the production process (Fig. 2), especially $\mathrm{NaOH}$ (Table 2). Heat and electricity used during DBF production give rise to significant energy demand that can be mitigated through use of non-fossil electricity and waste heat from biogas-fed combined heat and power plants, resulting in a net energy demand of below $30 \mathrm{MJ} \mathrm{m}^{-3} \mathrm{LD}$ treated for best case DBF extraction, and possibly even resulting in a net credit for CED at the low end of the uncertainty range (Fig. 2). For context, the net CED burden in the DBF-2 scenario would offset $4 \%$ of the net CED benefit arising from the digestion of the $1.2 \mathrm{Mg}$ of food waste substrate producing $1 \mathrm{~m}^{3}$ of LD (Fig. S1) ${ }^{14}$. 
conventional management of LD (Fig. 2). For DBF, embodied GWP in chemical inputs, $\mathrm{N}_{2} \mathrm{O}$ emissions from field application and effluent management in a constructed wetland, and $\mathrm{CO}_{2}$ emissions from natural gas heating, are cumulatively greater than GWP avoidance achieved through fertilizer substitution. However, if non-fossil electricity and heat sources are used (DBF-3), DBF production and use becomes close to carbon neutral. For $L D, \mathrm{~N}_{2} \mathrm{O}$ emissions from field application are the main source of GWP, and these emissions are higher for the better case scenarios (LD-1 and LD-2) than the worse scenarios (LD-3 and LD-4) owing to less loss of $\mathrm{N}$ during storage in the former scenarios. However, overall GWP burdens are significantly greater for LD-3 and LD-4 overall owing to high $\mathrm{CH}_{4}$ losses, and indirect $\mathrm{N}_{2} \mathrm{O}$ following $\mathrm{NH}_{3}$ losses, during open tank and lagoon storage of $\mathrm{LD}$, respectively. Thus, despite significant emissions in the production process, DBF can mitigate GHG emissions arising from LD management by avoiding direct and indirect $\mathrm{N}_{2} \mathrm{O}$ and $\mathrm{CH}_{4}$ emissions from digestate storage and field-application, and by increasing fertilizer substitution. For context, under default assumptions DBF can enhance the overall GHG abatement potential of food waste digestion by $8 \%$ (Fig. S1), but under the most pessimistic assumptions for DBF it could reduce the overall GHG abatement potential of food waste digestion by $4 \%$.

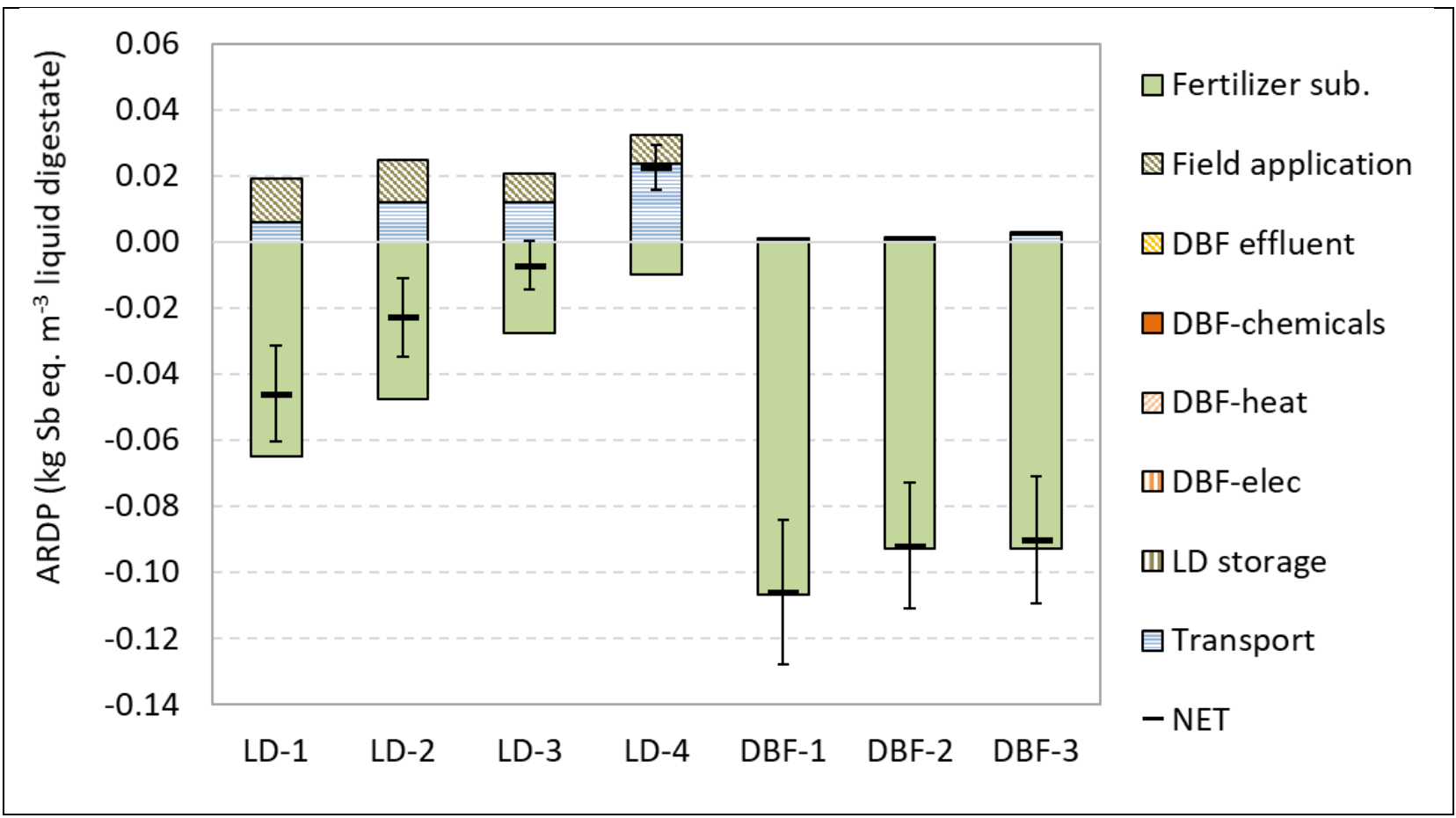




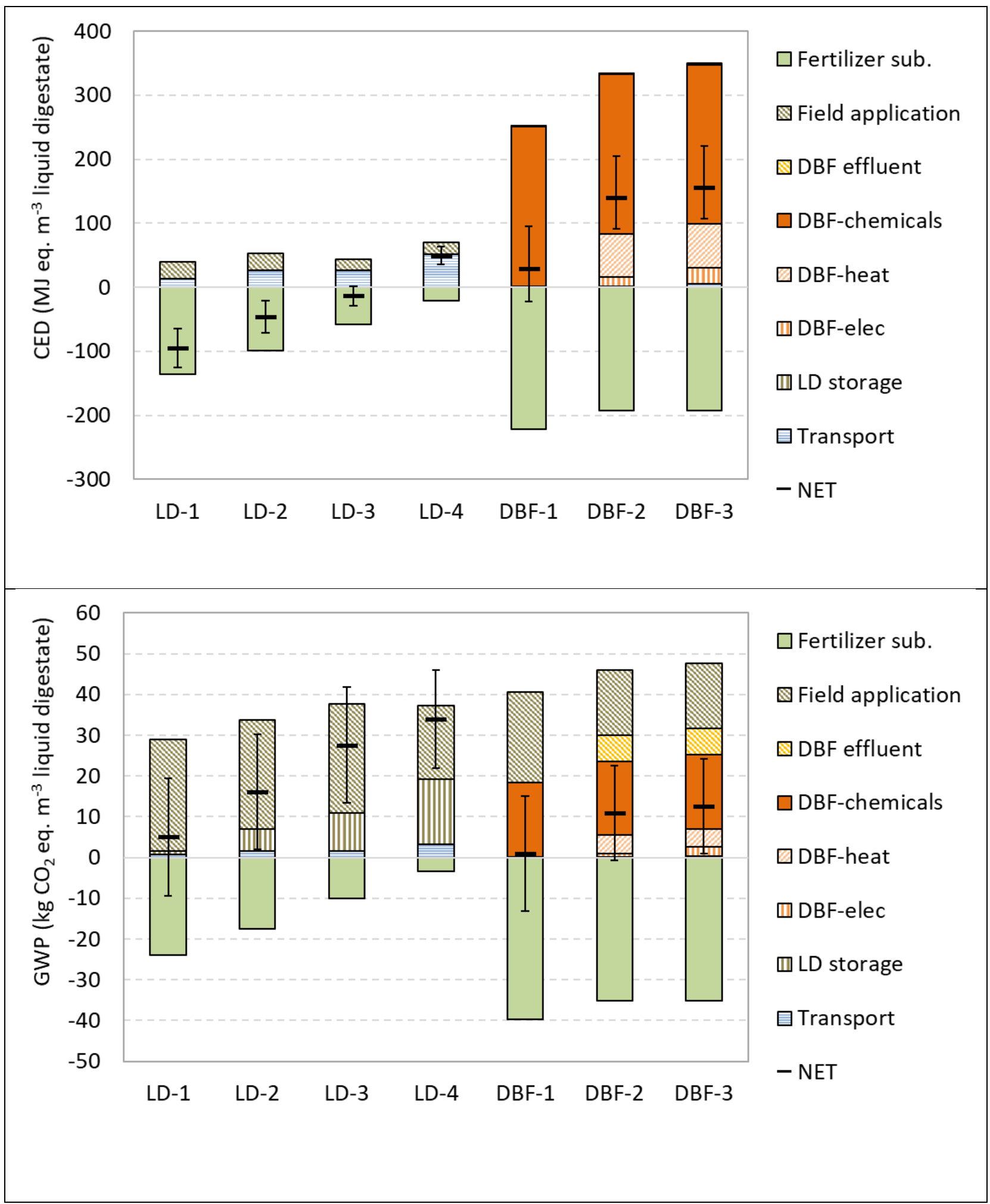

Figure 2. Environmental balance per $\mathrm{m}^{3}$ of liquid digestate (LD) managed along a spectrum of best (LD-1) to worst (LD-4) practice, and upcycled digestate biofertilizer managed along a spectrum of best (DBF-1) to worst (DBF-3) practice. Results displayed for abiotic resource depletion (ARD, top), cumulative energy demand (CED, middle) and global warming potential (GWP, bottom) 
277 Results in Fig. 3 and Table S3 confirm those of previous studies indicating high acidification and 278 eutrophication burdens from digestate storage and field application ${ }^{8,14,31,47}$. Acidification burdens are driven by $\mathrm{NH}_{3}$ emissions, which are related to methods of digestate storage and application, and range from 0.7 to $4.3 \mathrm{~kg} \mathrm{SO}{ }_{2}$ eq. per $\mathrm{m}^{3} \mathrm{LD}$ for optimum management (LD-1) and worst-case management (LD-4), respectively (Fig. 3). Upgrading LD into DBF avoids these emissions, and reduces the net acidification burden of food waste digestion by up to $73 \%$ (Fig. S1), representing a potentially important mitigation option for perhaps the most significant environmental hotspot of $A D$ systems ${ }^{14,50,51}$. Eutrophication burdens follow a similar though less pronounced pattern to acidification, increasing from 0.4 to $1.1 \mathrm{~kg} \mathrm{PO}_{4}$ eq. per $\mathrm{m}^{3}$ of LD for optimum management (LD-1) and worst-case management (LD-4), respectively (Fig. 3). The production and use of DBF achieves a net reduction in eutrophication owing to the avoidance of upstream extraction and processing of nutrients for synthetic fertilizers (field emissions are assumed to be the same for synthetic fertilizers and DBF). Under default assumptions, DBF extraction reduces the net eutrophication burden of food waste digestion by $85 \%$ (Fig. S1). Thus, upgrading LD to DBF largey mitigates a second environmental hotspot of digestate use specifically, and $A D$ systems in genera ${ }^{14,50,51}$. 


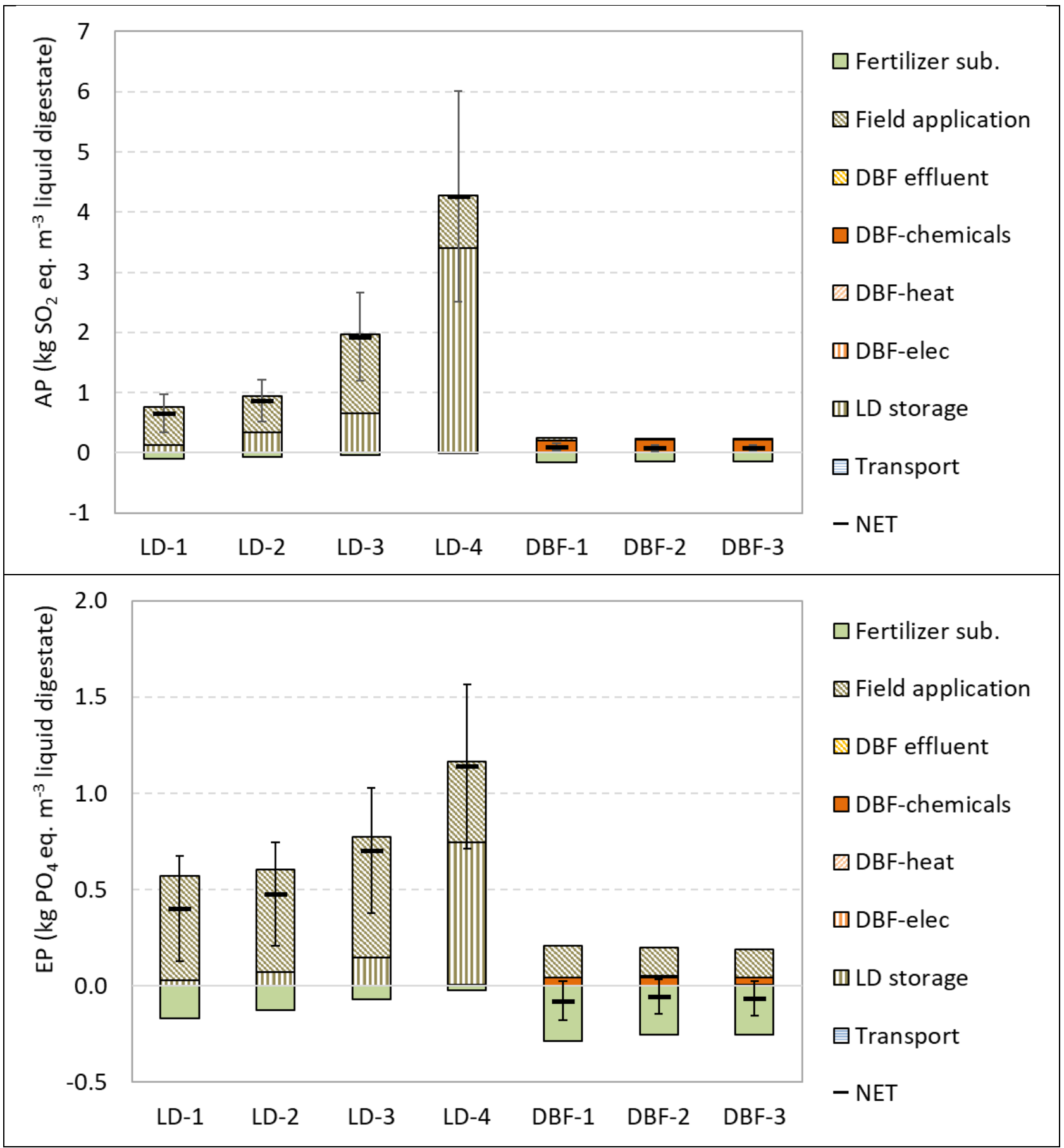

Figure 3. Environmental balance per $\mathrm{m}^{3}$ of liquid digestate (LD) managed along a spectrum of best (LD-1) to worst (LD-4) practice or upcycled into digestate biofertilizer (DBF), for acidification potential (AP, top) and eutrophication potential (EP, bottom).

\subsection{Abatement potential}

A recent survey of $A D$ operators indicated that open tank and lagoon storage systems predominate ${ }^{14}$.

Although almost one third of large AD plants were found to have sealed digestate storage tanks ${ }^{14}$, 
digestate sent to farms is likely to be stored in open tanks if it is not spread immediately, supporting our default assumption of open-tank storage (LD-3). Producing DBF at medium efficiency (DBF-2) from LD that would otherwise be handled in such a way would give rise to savings of $0.085 \mathrm{~kg}$ Sb eq., 1.85 $\mathrm{kg} \mathrm{SO}_{2}$ eq., $0.76 \mathrm{~kg} \mathrm{PO}_{4}$ eq. and $16.8 \mathrm{~kg} \mathrm{CO}_{2}$ eq. per $\mathrm{m}^{3}$ of $\mathrm{LD}$ upcycled to $\mathrm{DBF}$, though cumulative energy demand would increase by $154 \mathrm{MJ}$ eq. (Table S4). It is worth noting that a shift towards best practice in LD handling (LD-1) from default practice (LD-3) would also lead to significant environmental savings, and outperform DBF in terms of cumulative energy demand and global warming potential, though fall short of DBF in terms of the abatement of acidification, eutrophication and resource depletion hotspots (Table S4; Fig. S1; Fig. S2). Achieving environmental savings from best practice in digestate management would require all biogas plants to install sealed tank storage of digestate, all LD to be transported to land producing crops requiring all the nutrients in the LD, and all LD to be spread via shallow injection at the optimum time for crop uptake. There would be significant technical and logistical barriers to implementing such practices universally, and costs could exceed the projected costs of commercial DBF extraction which are estimated to be $€ 5-10$ per $\mathrm{m}^{3} \mathrm{LD}$.

Extrapolated to an ambitious future scenario in which $25 \%$ of global food waste is treated by $A D$ (detailed in S6), the annual mitigation potential of upgrading all LD would equate to approximately $439 \mathrm{Gg} \mathrm{SO}_{2}$ eq., $22.6 \mathrm{Gg}$ Sb eq. and $4465 \mathrm{Gg} \mathrm{CO}_{2}$ eq. under default assumptions (Table S5). Normalisation of these theoretical abatement potentials (Fig. S2) indicates that abiotic resource depletion and acidification potential would be the impact categories most benefitted, with global burdens reduced by up to $1 \%$ and $0.2 \%$, respectively, under default assumptions, with a minor tradeoff in cumulative energy demand which would increase by $0.01 \%$.

\section{Recommendations}

In summary, expanded boundary LCA highlights the relative importance of environmental credits attributed to differential rates of fertilizer substitution when comparing the overall environmental 
balance of liquid digestate handling and use with the production and use of biofertilizer extracted from liquid digestate via struvite precipitation and ammonia stripping. Avoided gaseous emissions during storage and spreading of liquid digestate, and enhanced fertilizer substitution arising from more targeted application of the versatile biofertilizer product, mean that extraction of biofertilizer from liquid digestate can achieve significant environmental savings. Normalization indicates that the identified trade-off of higher cumulative energy demand is comparatively minor, and could be mitigated by use of renewable energy or surplus biogas heat. The avoidance of $\mathrm{NH}_{3}$ emissions and conservation of elemental resources appear to be the most significant advantages of biofertilizer production and use, which can help to close nutrient loops. External damage costs of $\mathrm{NH}_{3}$ emissions are estimated at approximately $€ 3000$ per tonne ${ }^{52}$, suggesting that the considerable $\mathrm{NH}_{3}$ abatement achieved by upgrading LD to DBF could be of significant public good benefit, and potentially worthy of subsidy support or regulatory push via tighter emission standards for digestate (and slurry) management. On the basis of these results, we would recommend:

- Further research into digestate management practices by farmers to better estimate associated emissions and actual, rather than theoretical, fertilizer substitution

- Detailed techno-economic assessment of DBF versus better management practices for digestate to identify potential contexts for cost-effective deployment of DBF production

- Investment into commercial development of struvite extraction and ammonia stripping from digestate, to optimise process efficiency and reduce costs

- Policies to drive pollution mitigating technologies such as biofertilizer extraction from digestate and other nutrient-rich residues, such as pollution taxes and/or tighter controls on residue storage and (rates, methods and timings of) application

\section{Acknowledgements}

This work was supported by the Natural Science and Engineering Research Council of Canada through the award of an NSERC Discovery Grant (RGPIN-2017-04838) and Welsh Government and Higher 
Supporting Information. Five tables containing information on liquid digestate characteristics, normalized environmental loading changes.

\section{References}

(1) Steffen, W.; Richardson, K.; Rockström, J.; Cornell, S. E.; Fetzer, I.; Bennett, E. M.; Biggs, R.;

(6) Holm-Nielsen, J. B.; Al Seadi, T.; Oleskowicz-Popiel, P. The future of anaerobic digestion and biogas utilization. Bioresour. Technol. 2009, 100 (22), 5478-5484.

(3) Sutton, M. A.; Bleeker, A.; Howard, C. .; Bekunda, M.; Grizzetti, B.; de Vries, W.; van Grinsven, H. J. M.; Abrol, Y. P.; Adhya, T. K.; Billen, G.; Davidson, E. A.; Datta, A.; Diaz, R.; Erisman, J. W.; X.J., L.; Oenema, O.; Palm, C.; Raghuram, N.; Reis, S.; Scholz, R. W.; Sims, T.; Westhoek, H.; Zhang, F. S. Our Nutrient World: The challenge to produce more food and energy with less pollution; Edinburgh, 2013.

(4) Cordell, D.; Drangert, J.-O.; White, S. The story of phosphorus: Global food security and food for thought. Glob. Environ. Chang. 2009, 19 (2), 292-305.

(5) Schipper, W. Phosphorus: Too Big to Fail. Eur. J. Inorg. Chem. 2014, 2014 (10), 1567-1571.

(7) Vaneeckhaute, C.; Meers, E.; Michels, E.; Buysse, J.; Tack, F. M. G. Ecological and economic 
benefits of the application of bio-based mineral fertilizers in modern agriculture. Biomass and Bioenergy 2013, 49, 239-248.

(8) Rehl, T.; Müller, J. Life cycle assessment of biogas digestate processing technologies. Resour. Conserv. Recycl. 2011, 56 (1), 92-104.

(9) Nkoa, R. Agricultural benefits and environmental risks of soil fertilization with anaerobic

(10) FNR. Guide to Biogas: From production to use; Gülzow, 2012.

(11) British Standards Institute. PAS 110:2014 Specification for whole digestate, separated liquor and separated fibre derived from the anaerobic digestion of source-segregated biodegradable materials Publishing and copyright information, 2nd ed.; London, 2014.

(12) Fedorniak, G. Efficiency of digestate use from a large centralised AD plant, Bangor University, 2017.

(13) AHDB. Nutrient Management Guide (RB209); Stoneleigh, 2017.

(14) Styles, D.; Dominguez, E. M.; Chadwick, D. Environmental balance of the of the UK biogas sector: An evaluation by consequential life cycle assessment. Sci. Total Environ. 2016, 560$561,241-253$.

(15) ten Hoeve, M.; Hutchings, N. J.; Peters, G. M.; Svanström, M.; Jensen, L. S.; Bruun, S. Life cycle assessment of pig slurry treatment technologies for nutrient redistribution in Denmark. J. Environ. Manage. 2014, 132, 60-70.

(16) Fangueiro, D.; Coutinho, J.; Chadwick, D.; Moreira, N.; Trindade, H.; D.F. McCrory. Effect of Cattle Slurry Separation on Greenhouse Gas and Ammonia Emissions during Storage. J. Environ. Qual. 2008, 37 (6), 2322.

(17) Vaneeckhaute, C.; Lebuf, V.; Michels, E.; Belia, E.; Vanrolleghem, P. A.; Tack, F. M. G.; Meers, 

Classification. Waste and Biomass Valorization 2017, 8 (1), 21-40.

399

400

401

402

(18) Xu, J.; Zhao, Y.; Zhao, G.; Zhang, H. Nutrient removal and biogas upgrading by integrating freshwater algae cultivation with piggery anaerobic digestate liquid treatment. Appl. Microbiol. Biotechnol. 2015, 99 (15), 6493-6501.

(19) Sigurnjak, I.; Vaneeckhaute, C.; Michels, E.; Ryckaert, B.; Ghekiere, G.; Tack, F. M. G.; Meers, E. Fertilizer performance of liquid fraction of digestate as synthetic nitrogen substitute in silage maize cultivation for three consecutive years. Sci. Total Environ. 2017, 599-600, 18851894.

(20) Vázquez-Rowe, I.; Golkowska, K.; Lebuf, V.; Vaneeckhaute, C.; Michels, E.; Meers, E.; Benetto, E.; Koster, D. Environmental assessment of digestate treatment technologies using LCA methodology. Waste Manag. 2015, 43, 442-459.

(21) Hanserud, O. S.; Cherubini, F.; Øgaard, A. F.; Müller, D. B.; Brattebø, H. Choice of mineral fertilizer substitution principle strongly influences LCA environmental benefits of nutrient cycling in the agri-food system. Sci. Total Environ. 2018, 615, 219-227.

(22) Thelin, G. EkoBalans production process report; 2017.

(23) Nicholson, F. A.; Bhogal, A.; Chadwick, D.; Gill, E.; Gooday, R. D.; Lord, E.; Misselbrook, T.; Rollett, A. J.; Sagoo, E.; Smith, K. A.; Thorman, R. E.; Williams, J. R.; Chambers, B. J. An enhanced software tool to support better use of manure nutrients: MANNER-NPK. Soil Use Manag. 2013, 29 (4), 473-484.

(24) Misselbrook, TH; Gilhespy, SL; Cardenas, LM; Williams, J; Dragosits, U. Inventory of Ammonia Emissions from UK Agriculture 2014 Inventory of Ammonia Emissions from UK Agriculture$2014 ; 2015$. 
(25) Rodhe, L. K. K.; Ascue, J.; Willén, A.; Persson, B. V.; Nordberg, Å. Greenhouse gas emissions from storage and field application of anaerobically digested and non-digested cattle slurry. Agric. Ecosyst. Environ. 2015, 199, 358-368.

(26) Guštin, S.; Marinšek-Logar, R.; Roš, M.; Figueroa, M.; Franco, A.; Mosquera-Corral, A.; Campos, J. L.; Mendez, R. Effect of pH, temperature and air flow rate on the continuous ammonia stripping of the anaerobic digestion effluent. Process Saf. Environ. Prot. 2011, 89 (1), 61-66.

(27) Finkbeiner, M.; Inaba, A.; Tan, R. B. H.; Christiansen, K.; Klüppel, H.-J. The New International Standards for Life Cycle Assessment: ISO 14040 and ISO 14044. Int J LCA 2006, 11 (112), 8085.

(28) BSI. PAS 2050:2011 Specification for the assessment of the life cycle greenhouse gas emissions of goods and services; 2011.

(29) CML - Department of Industrial Ecology. CML-IA Characterisation Factors - Leiden University https://www.universiteitleiden.nl/en/research/research-output/science/cml-iacharacterisation-factors (accessed Jul 20, 2017).

(30) Adams, P. W. R.; Mezzullo, W. G.; McManus, M. C. Biomass sustainability criteria: Greenhouse gas accounting issues for biogas and biomethane facilities. Energy Policy 2015, 87, 95-109.

(31) Lijó, L.; González-García, S.; Bacenetti, J.; Fiala, M.; Feijoo, G.; Moreira, M. T. Assuring the sustainable production of biogas from anaerobic mono-digestion. J. Clean. Prod. 2014, 72, 23-34.

(32) Banks, C. Optimising anaerobic digestion: Evaluating the Potential for Anaerobic Digestion to provide Energy and Soil amendment; University of Reading, 2009; p 39. 
(33) IPCC. 2006 IPCC Guidelines for National Greenhouse Gas Inventories Volume 4 Chapter 2; 2006.

(34) Dalgaard, T.; Halberg, N.; Porter, J. R. A model for fossil energy use in Danish agriculture used to compare organic and conventional farming. Agric. Ecosyst. Environ. 2001, 87 (1), 51-65.

(35) Bittman, S.; Dedina, M.; Howard, C. M.; Oenema, O.; Sutton, M. A. Options for Ammonia Mitigation Guidance from the UNECE Task Force on Reactive Nitrogen. 2014.

(36) Duffy, P.; Hanley, E.; Hyde, B.; O 'brien, P.; Ponzi, J.; Cotter, E.; Black, K. IRELAND NATIONAL

(37) Withers, P. J. A.; Lord, E. I. Agricultural nutrient inputs to rivers and groundwaters in the UK: policy, environmental management and research needs. Sci. Total Environ. 2002, 282-283, 9-

(38) Styles, D.; Gibbons, J.; Williams, A. P.; Dauber, J.; Stichnothe, H.; Urban, B.; Chadwick, D. R.; 
(42) Westhoek, H.; Rood, T.; van den Berg, M.; Janse, J.; Nijdam, D.; Reudink, M.; Stehfest, E. The proTein puzzle; The Hague, 2011.

(43) IPCC. 2006 IPCC Guidelines for National Greenhouse Gas Inventories Volume 4 Chapter 5; 2006.

(44) Wernet, G.; Bauer, C.; Steubing, B.; Reinhard, J.; Moreno-Ruiz, E.; Weidema, B. The ecoinvent database version 3 (part I): overview and methodology. Int. J. Life Cycle Assess. 2016, 21 (9), $1218-1230$.

(45) Gallagher, J.; Styles, D.; McNabola, A.; Williams, A. P. Current and Future Environmental Balance of Small-Scale Run-of-River Hydropower. Environ. Sci. Technol. 2015, 49 (10), 63446351.

(46) Talboys, P. J.; Heppell, J.; Roose, T.; Healey, J. R.; Jones, D. L.; Withers, P. J. A. Struvite: a slowrelease fertiliser for sustainable phosphorus management? Plant Soil 2016, 401 (1-2), 109123.

(47) Bacenetti, J.; Negri, M.; Fiala, M.; González-García, S. Anaerobic digestion of different feedstocks: Impact on energetic and environmental balances of biogas process. Sci. Total Environ. 2013, 463-464, 541-551.

(48) Lijó, L.; González-García, S.; Bacenetti, J.; Fiala, M.; Feijoo, G.; Lema, J. M.; Moreira, M. T. Life Cycle Assessment of electricity production in Italy from anaerobic co-digestion of pig slurry and energy crops. Renew. Energy 2014, 68, 625-635.

(49) Styles, D.; Gibbons, J.; Williams, A. P.; Stichnothe, H.; Chadwick, D. R.; Healey, J. R. Cattle feed or bioenergy? Consequential life cycle assessment of biogas feedstock options on dairy farms. GCB Bioenergy 2015, 7 (5), 1034-1049.

(50) Hijazi, O.; Munro, S.; Zerhusen, B.; Effenberger, M. Review of life cycle assessment for biogas 

production in Europe. Renew. Sustain. Energy Rev. 2016, 54, 1291-1300.

490 (51) Rehl, T.; Lansche, J.; Müller, J. Life cycle assessment of energy generation from biogasAttributional vs. consequential approach. Renew. Sustain. Energy Rev. 2012, 16 (6), 37663775.

493

(52) DEFRA. Air quality: economic analysis - GOV.UK https://www.gov.uk/guidance/air-quality494 economic-analysis (accessed Aug 11, 2017).

495 